\title{
Akademia og akademiet
}

\author{
Ordet akademia brukes gjerne som betegnelse på den akademiske verden. Hva er egentlig forskjellen \\ på akademia og akademiet?
}

I Tidsskriftet nr. 7/2014 hadde Ragnar Stien en artikkel om Ardis Storm-Mathisen (1912-2000), den kvinnelige nevrologen som fikk underkjent sin doktoravhandling og som kan ha blitt forbigått ved flere ansettelser (1). Artikkelen hadde tittelen Kvinner $i$ akademia - en trussel mot menn? Da vi i redaksjonen skulle omtale artikkelen i spalten Les mer om valgte vi å skrive: Var hun en trussel for menn i akademiet? Tanken var at akademia kunne erstattes med den mer «norske» og «folkelige» formen akademiet - på samme måte som man snakker om $i$ vitenskapen, $i$ kunsten og $i$ politikken.

\section{Opprinnelse og bruk}

Ordet akademi har sin opprinnelse i det klassiske Grekenland. Platon underviste sine elever i en lund som het Akadémeia, like nord for Aten. Gjennom latin ble etter hvert academia en vanlig brukt betegnelse på vitenskapelige og kunstneriske institusjoner i hele Europa $(2,3)$.

I våre dager har akademi ifølge ordbøkene to betydninger: For det første som en betegnelse på høyere undervisningsinstitusjoner, f.eks. et kunstakademi. Dette er i samsvar med den opprinnelige betydningen. For det andre brukes ordet om foreninger for forskere eller kunstnere, slik som Det Norske Videnskaps-Akademi. Dette er nok den mest utbredte betydningen i dag (4).

På engelsk er ordet academia i flere tiår brukt som en betegnelse på det man kan kalle den akademiske verden. Den norske varianten akademia var lite brukt helt frem til 1990-årene (5). I tekstarkivet Retriever er det færre enn fem treff per år frem til midten av 1990-årene, men fra 1996 kom ordet stadig oftere i bruk - med rundt 100 treff i 2001, over 500 treff i 2003 og over 2000 treff per år etter 2009. Tilsvarende utvikling har man sett i Danmark, der ordet er kjent siden 1996 (6).

På norsk regnes akademia som et nyord (5) og er definert som en betegnelse på «den akademiske verden, universitets- og (høyskole)miljøene» (7). Men ordet er ikke oppført i Bokmålsordboka, Nynorskordboka eller Tanums store rettskrivningsordbok. Derimot står det i Store norske ordbok, Store norske leksikon og Aftenpostens rettskrivningsordliste. Ordet er etablert med en egen uttale - med trykk på i-en.

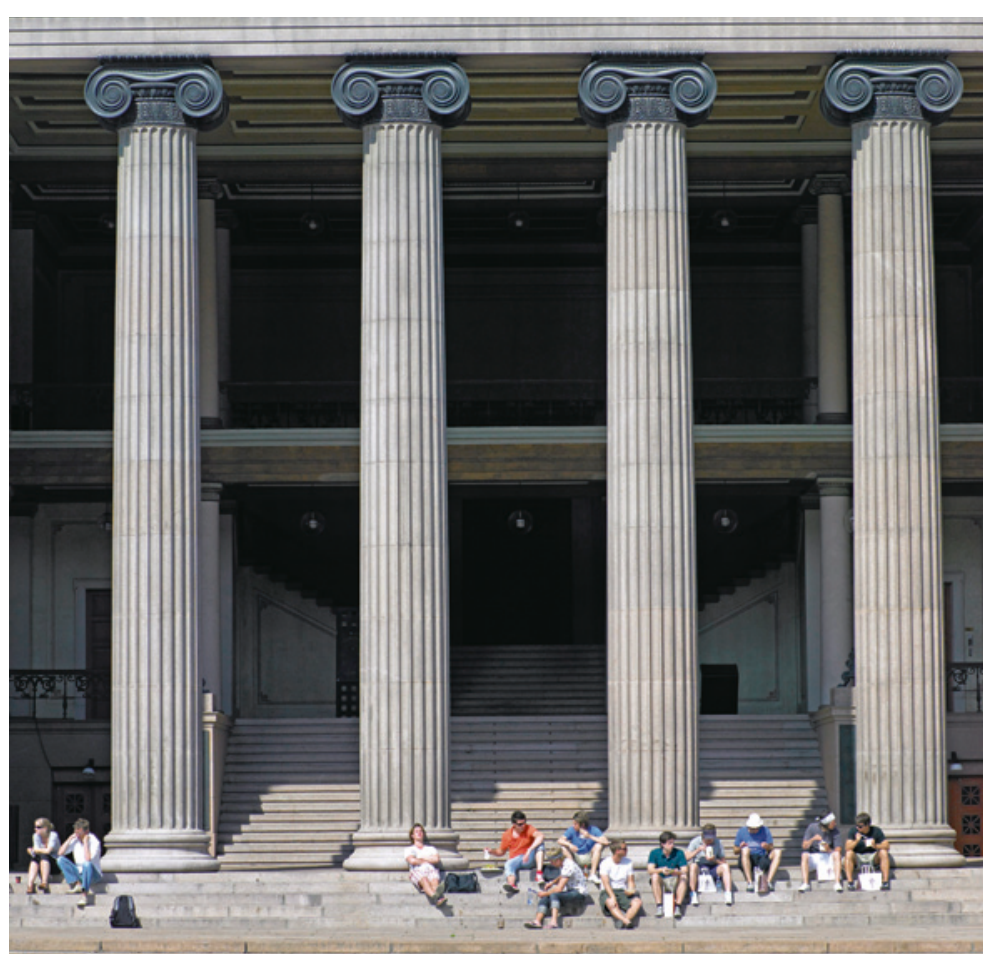

Akademia. Foto: (C) Svein Grønvold / NN / Samfoto

I ordbøkene er det ingen tegn til at akademiet kan brukes synonymt med akademia. Vi henvendte oss derfor til Språkrådet for å få deres vurdering. Heller ikke der var det støtte å få. Selv om det er vanskelig å finne tegn til denne type betydningsutvidelser ved søk i vanlig brukte ordbrukskilder, har rådet «lite tro på at ordet kan være særlig mye brukt slik du skriver dere har gjort i tidsskriftet deres», skriver seniorrådgiver Marit Hovdenak i Språkrådet til oss i en e-post.

Vi vil i fremtiden holde oss til akademia som den korrekte betegnelsen for «den akademiske verden». Ordet er kommet for å bli - det gir en rekke treff både på Tidsskriftets og Språkrådets nettsider. Det er nok bare et tidsspørsmål før det kommer på plass i ordbøkene.

\section{Erlend Hem}

erlend.hem@medisin.uio.no

Petter Gjersvik

Tidsskriftet
Erlend Hem (f. 1970) er dr.med. og tidligere assisterende sjefredaktør i Tidsskriftet.

Petter Gjersvik (f. 1952) er dr.med., medisinsk redaktør i Tidsskriftet og førsteamanuensis ved Universitetet i Oslo.

\section{Litteratur}

1. Stien R. Kvinner i akademia - en trussel mot menn? Tidsskr Nor Legeforen 2014: 134: 736-8.

2. akademi. I: Rosbach JH. Etymologi for alle. Oslo: Pax, 2009: 10

3. de Caprona Y. Norsk etymologisk ordbok: tematisk ordnet. Oslo: Kagge, 2013: 963

4. Amundsen L, Skoie H. (6.11.2013). Akademi. I: Store norske leksikon. https://snl.no/akademi (10.4.2014).

5. Akademia, akademia. I: Guttu T, Wangensteen B, red Nyord i norsk. Oslo: Kunnskapsforlaget, 2012: 18

6. akademia. I: Den danske ordbog. Det Danske Sprog-og Litteraturselskab. http://ordnet.dk/ddo/ ordbog?query=akademia\&tab=for (10.4.2014).

7. akademia. I: Guttu T, red. Norsk ordbok. http://ordnett.no/search?search=akademia (10.4.2014).

Mottatt 5.10. 2014, første revisjon innsendt 19.12 2014, godkjent 28.1. 2015. Redaktør: Marit Skaar Fjellhaug. 